\title{
Efektivitas Dan Kontribusi Penerimaan Bea Perolehan Hak Atas Tanah Dan Bangunan Dalam Rangka Peningkatan Pendapatan Asli Daerah di Kabupaten Gunung Kidul
}

\author{
Tatik $^{1}$, Yestias Maharani ${ }^{2}$, Zulfa Farah $\mathbf{H H}^{3}$, Muhammad Manar Barmawi ${ }^{4}$ \\ Fakultas Bisnis dan Ekonomika, Universitas Islam Indonesia, Yogyakarta ${ }^{1,2,3}$ \\ Sekolah Tinggi Ilmu Manajemen (STIM) YKPN, Yogyakarta ${ }^{4}$ \\ Email : tatik.pawiro@uii.ac.id ${ }^{1}$
}

\begin{abstract}
Abstrak
Penelitian ini bertujuan untuk mengetahui efektivitas dan kontribusi penerimaan BPHTB (Bea Perolehan Hak Atas Tanah dan Bangunan) dalam rangka peningkatan pendapatan asli daerah. BPHTB merupakan pajak atas perolehan hak tanah dan bangunan baik oleh pribadi maupun badan. Penelitian menggunakan metode kualitatif dengan pendekatan studi kasus pada Kabupaten Gunung Kidul - Yogyakarta. Data diperoleh dari dokumen dan wawancara. Informan/narasumber berasal dari berbagai pihak yang kompeten memberikan informasi yang diperlukan. Hasil penelitian ini menunjukkan bahwa penerimaan Bea Perolehan Hak Atas Tanah dan Bangunan di Kabupaten Gunung Kidul dapat dikategorikan cukup efektif, namun kontribusi dari Bea Perolehan Hak Atas Tanah dan Bangunan terhadap Pendapatan Asli Daerah (PAD) masih sangat kurang.

Kata Kunci: Efektivitas, Kontribusi, Pajak, Pendapatan Asli Daerah
\end{abstract}

\section{Pendahuluan}

\subsection{Latar Belakang}

Kabupaten Gunung Kidul merupakan salah satu kabupaten dari lima kabupaten di Daerah Istimewa Yogyakarta - Indonesia. Kabupaten Gunung Kidul memiliki daerah terluas dibandingkan kabupaten lainnya dan juga memiliki kekayaan alam yang melimpah. Kekayaan alam yang melimpah tersebut dapat menjadi potensi besar untuk meningkatkan perekonomian daerah melalui optimalisasi Pendapatan Asli Daerah (PAD). (Papang Permadi dkk, 2014)

Pendapatan Asli Daerah (PAD) merupakan salah satu sumber pendanaan bagi daerah kabupaten/kota dengan salah satu komponennya berupa pajak daerah dan retribusi daerah. Pajak daerah adalah kontribusi wajib oleh orang pribadi atau badan yang bersifat memaksa dengan tanpa mendapatkan imbalan secara langsung dan digunakan untuk keperluan daerahnya bagi kemakmuran rakyat. Retribusi daerah adalah pemungutan dari daerah sebagai pembayaran atas jasa atau pemberian izin tertentu yang khusus disediakan dan/atau diberikan oleh pemerintah daerah untuk kepentingan pribadi atau badan.

Semakin tinggi kontribusi yang diberikan Pendapatan Asli Daerah (PAD) maka 
semakin tinggi kemampuan daerah untuk membiayai penyelenggaraan pemerintahan serta pembangunan daerah. Pajak daerah mempunyai peranan yang sangat penting dalam membiayai penyelenggaran pemerintahan serta pembangunan disuatu daerah. Kemampuan pemerintah daerah dalam memungut pajak daerah merupakan salah satu tolok ukur dalam pelaksanaan otonomi daerah.

Pemerintah daerah perlu meningkatkan secara maksimal potensi yang ada khususnya potensi yang akan dikenakan pajak daerah. Jenis pajak daerah yang dipungut oleh Pemerintah Daerah Kabupaten Gunungkidul diatur dalam Undang-Undang Nomor 1 Tahun 2011, terdiri dari Pajak Hotel, Pajak Restoran, Pajak Hiburan, Pajak Parkir, Pajak Reklame, Pajak Air Tanah, Pajak Penerangan Jalan (PPJ), Pajak Mineral Bukan Logam dan Batuan, Pajak Bumi dan Bangunan Pedesaan dan Perkotaan (PBB-P2), Bea Perolehan Hak atas Tanah dan Bangunan (BPHTB).

Bea Perolehan Hak atas Tanah dan Bangunan (BPHTB) merupakan salah satu bagian dari jenis pajak daerah. Bea Perolehan Hak atas Tanah dan Bangunan ini merupakan pajak yang dilimpahkan oleh pemerintah pusat kepada pemerintah daerah. Menurut Undang-Undang Nomor 21 Tahun 1997 sebagaimana telah diubah dengan UndangUndang Nomor 20 tahun 2000 tentang BPHTB. BPHTB nerupakan pajak yang dikenakan atas perolehan hak atas tanah dan atau bangunan, yang selanjutnya disebut pajak. Jadi BPHTB sama dengan pajak perolehan hak atas tanah dan bangunan.

Menurut Undang-Undang BPHTB, Perolehan Hak atas Tanah dan atau Bangunan adalah perbuatan atau peristiwa hukum yang mengakibatkan diperolehannya hak atas tanah dan atau bangunan oleh orang pribadi atau badan. Kewenangan pemungutan BPHTB dari pemerintah pusat kepada pemerintah daerah sesuai dengan Undang-Undang Nomor 28 tahun 2009 tentang Pajak Daerah dan Retribusi Daerah. Dengan demikian Kantor Pelayanan Pajak Pratama sudah tidak lagi melayani pengelolaan pelayanan BPHTB tersebut, sehingga wajib pajak yang akan melaporkan pembayaran BPHTB sehubungan dengan proses transaksi properti yang dilakukannya akan langsung ditangani oleh Pemerintah Daerah atau Kabupaten/Kota.

Ditetapkannya BPHTB menjadi tanggung jawab daerah maka perlu diatur dengan suatu peraturan yang dapat mendorong daerah untuk mempersiapkan segala sesuatu yang diperlukan dalam pelaksanaan pemungutan BPHTB. Pemungutan BPHTB diawali dengan Peraturan Daerah (PERDA). Oleh karena itu, salah satu indikator yang dapat digunakan untuk melihat kesiapan daerah memungut BPHTB adalah perkembangan penerbitan Peraturan Daerah (PERDA) tentang BPHTB oleh Kabupaten/Kota. 


\subsection{Rumusan Masalah}

1. Apakah penerimaan Bea Perolehan Hak atas Tanah dan Bangunan di Badan Keuangan dan Aset Daerah Kabupaten Gunung Kidul telah efektif?

2. Berapakah besarnya kontribusi penerimaan Bea Perolehan Hak atas Tanah dan Bangunan bagi Pendapatan Asli Daerah di Kabupaten Gunung Kidul?

\subsection{Tujuan Penelitian}

1. Menganalisis efektivitas dan kontribusi penerimaan Bea Perolehan Hak atas Tanah dan Bangunan di Badan Keuangan dan Aset Daerah Kabupaten Gunung Kidul.

2. Mengetahui besarnya kontribusi penerimaan Bea Perolehan Hak atas Tanah dan Bangunan bagi Pendapatan Asli Daerah di Kabupaten Gunung Kidul.

\section{LANDASAN TEORI}

\subsection{PAD (Pendapatan Asli Daerah)}

Karakteristik yang menunjukkan suatu daerah otonom yaitu terletak pada kemampuan untuk memenuhi kebutuhan keuangan daerahnya. Artinya daerah otonom harus memiliki kewenangan dan kemampuan untuk menggali sumber-sumber keuangan sendiri, sedangkan ketergantungan pada bantuan pemerintah pusat harus seminimal mungkin, sehingga PAD (Pendapatan Asli Daerah) harus menjadi bagian sumber keuangan terbesar yang didukung oleh kebijakan pembagian keuangan pusat dan daerah sebagai prasyarat sistem pemerintahan Negara.

Dengan berlakunya Undang-Undang Nomor 32 Tahun 2004 tentang Pemerintahan Daerah sebagaimana telah diubah beberapa kali terakhir dengan Undang-Undang Nomor 12 Tahun 2008 tentang Pemerintahan Daerah dan menurut Undang-Undang Republik Indonesia Nomor 33 Tahun 2004 tentang Perimbangan Keuangan antara Pemerintah Pusat dan Pemerintah Daerah, maka penyelenggaraan pemerintahan daerah dilakukan dengan memberikan kewenangan yang seluas-luasnya, disertai dengan pemberian hak dan kewajiban menyelenggarakan otonomi daerah dalam kesatuan sistem penyelenggaraan pemerintahan Negara.

Sebagaimana telah dijelaskan dalam Undang-Undang diatas, kemudian dikeluarkan Undang-Undang Nomor 28 Tahun 2009 dalam rangka pembiayaan penyelenggaraan pemerintahan dan pelayanan kepada masyarakat, pemerintah pusat memberikan kewenangan pajak (taxing power) kepada daerah agar dapat berupaya mengoptimalkan Pendapatan Asli Daerah melalui Pajak Daerah dan Retribusi Daerah.

Dalam Undang-Undang Nomor 33 Tahun 2004 tentang Perimbangan keuangan antara Pusat dan daerah pasal 1 ayat 18 disebutkan bahwa, Pendapatan Asli Daerah (PAD) 
adalah pendapatan yang diperoleh Daerah yang dipungut berdasarkan Peraturan Daerah sesuai dengan peraturan perundang-undangan. Adapun tujuan PAD ini berdasarkan pasal 3 yakni memberikan kewenangan kepada Pemerintahan Daerah untuk mendanai pelaksanaan otonomi daerah sesuai dengan potensi daerah sebagai perwujudan desentralisasi.

Adapun sumber Pendapatan Asli Daerah (PAD) adalah hasil pajak daerah, hasil retribusi daerah, hasil perusahaan milik daerah dan hasil pengelolaan kekayaan daerah lainnya, serta lain-lain pendapatan asli daerah yang sah (hasil penjualan asset darerah yang tidak dipisahkan, penerimaan jasa giro, pendapatan bunga deposito, tuntutan ganti kerugian daerah, komisi, potongan dan selisih nilai tukar rupiah).

Menurut Soemitro (2014:1), pajak adalah iuran rakyat kepada kas Negara berdasarkan undang - undang (yang dapat dipaksakan) dengan tidak mendapat jasa timbal balik (kontraprestasi) yang langsung dapat ditunjukan, dan yang digunakan untuk membayar pengeluaran umum. Dan pajak daerah merupakan pajak yang dipungut oleh pemerintah daerah baik daerah tingkat I (pajak provinsi) maupun daerah tingkat II (pajak kabupaten/kota), dan digunakan untuk membiayai rumah tangga daerah masing-masing, misalnya Pajak Kendaraan Bermotor, Pajak hotel, Pajak restoran, Pajak Air Tanah, dan Bea Perolehan Hak atas Tanah dan Bangunan. (Siti Resmi, 2014).

\subsection{Bea Perolehan Hak atas Tanah dan Bangunan (BPHTB)}

Menurut Mardiasmo (2016), Bea Perolehan Hak atas Tanah dan Bangunan (BPHTB) adalah pajak yang dikenakan atas perolehan hak atas tanah dan /atau bangunan. Perolehan hak atas tanah dan/atau bangunan adalah perbuatan atau peristiwa hukum yang mengakibatkan diperolehnya hak atas tanah dan/atau bangunan oleh orang pribadi atau badan. Hak atas Tanah dan/atau Bangunan adalah hak atas tanah, termasuk hak pengelolaan, beserta bangunan di atasnya, sebagaimana dimaksud dalam undang-undang di bidang pertahanan dan bangunan.

Bea Perolehan Hak atas Tanah dan Bangunan (BPHTB) diataur dalam UndangUndang Nomor 21 tahun 1997 yang kemudian diubah dengan Undang-Undang Nomor 20 tahun 2000. Undang-Undang ini merupakan landasan hukum dalam pengenaan pajak sehubung dengan perolehan hak atas tanah dan bangunan.

Prinsip-prinsip yang dianut dalam undang-undang Bea Perolehan Hak atas Tanah dan Bangunan ini adalah: 
1. Pemenuhan kewajiban Bea Perolehan Hak atas Tanah dan Bangunan adalah berdasarkan sistem self assessment, yaitu Wajib Pajak menghitungdan membayar senidri utang pajaknya.

2. Besarnya tarif ditetapkan sebesar 5\% dari Nilai Perolehan Objek Pajak Kena Pajak.

3. Agar pelaksanaan undang-undang ini dapat berlaku secara efektif baik kepada Wajib Pajak maupun kepada pejabat-pejabat umum yang melanggar ketentuaan atau baik sanksi menurut peraturan perundang-undangan yang berlaku.

4. Hasil penerimaan Bea Perolehan Hak atas Tanah dan Bangunan merupakan penerimaan Negara yang sebagaian besar diserahkan kepada pemerintah daerah untuk meningkatkan pendapatan daerah guna membiayai penyelenggaraan pemerintah daerah dan dalam rangka memantapkan otonomi daerah.

Obyek BPHTB sebagaimana yang diatur dalam Pasal 1 Undang-Undang Nomor 21 Tahun 1997 sebagaimana telah diubah dengan Undang-Undang Nomor 20 Tahun 2000 tentang Bea Perolehan Hak atas Tanah dan Bangunan menyatakan bahwa BPHTB adalah pajak yang dikenakan atas perolehan hak atas tanah dan bangunan (selanjutnya disebut dengan pajak). Dengan demikian yang menjadi objek pajak adalah perolehan hak atas tanah dan bangunan dapat berupa tanah termasuk tanaman diatasnya, tanah dan bangunan diatasnya, serta bangunan.

Subjek pajak BPHTB adalah orang pribadi atau badan yang memperoleh hak atas tanah dan bangunan. Subjek pajak yang dikenakan kewajiban membayar pajak BPHTB tersebut menjadi wajib pajak menurut Undang-undang BPHTB. Adapun tarif yang ditetapkan atas pajak Bea Perolehan Hak atas Tanah dan Bangunan sebesar 5\% dari Nilai Perolehan Objek Pajak Kena Pajak.

\subsection{Efektivtias dan Kontribusi}

Efektivitas menggambarkan seberapa baik pekerjaan yang dilakukan, sejauh mana orang menghasilkan keluaran sesuai dengan yang diharapkan. Bungkaes (2013) menyatakan efektivitas merupakan hubungan antara output dan tujuan, dalam artian efektivitas adalah ukuran seberapa jauh tingkat output, kebijakan dan prosedur dari organisasi mencapai tujuan yang ditetapkan. Jadi efektivitas pajak daerah menunjukkan kemampuan pemerintah daerah dalam mengumpulkan pajak daerah sesuai dengan jumlah penerimaan pajak daerah yang ditargetkan. 
Untuk mengetahui Efektivitas menggunakan rumus berikut :

\begin{tabular}{c} 
Efektivitas $=\frac{\text { Realisasi }}{\text { Target }} \times 100 \%$ \\
\hline
\end{tabular}

Sumber : Halim, 2010

Hasil perhitungan efektivitas penerimaan Bea Perolehan Hak atas Tanah dan Bangunan kemudian dapat diintepretasikan sesuai kriteria kontribusi yaitu sangat efektif, efektif, cukup efektif, kurang efektif dan tidak efektif. Berikut ini dirincikan kriteria tersebut:

Tabel 1.5

Tabel Interpretasi Nilai Efektifitas

\begin{tabular}{ll}
\hline Persentase & Kriteria \\
\hline$>100 \%$ & Sangat Efektif \\
$90-100 \%$ & Efektif \\
$80-90 \%$ & Cukup Efektif \\
$60-80 \%$ & Kurang Efektifi \\
$<60 \%$ & Tidak Efektif \\
\hline
\end{tabular}

Sumber : Yulia Anggara Sari, 2010

Menurut Soerjono Soekanto (2015) mengartikan kontribusi sebagai bentuk iuran uang atau dana, bantuan tenaga, bantuan pemikiran, bantuan materi, dan segala acam bentuk bantuan yang kiranya dapat membantu suksesnya kegiatan pada suatu forum, perkumpulan dan lain sebagainya. Sedangkan analisis kontribusi digunakan untuk mengetahui sejauh mana Bea Perolehan Hak atas Tanah dan Bangunan memberikan sumbangan dalam pendapatan asli daerah.

Untuk mengetahui kontribusi BPHTB terhadap PAD digunakan rumus sebagai berikut :

Kontribusi BPHTB = Realisasi Penerimaan BPHTB X 100\%

Realisasi Penerimaan PAD

Sumber : Halim, 2010

Hasil perhitungan kontribusi Bea Perolehan Hak atas Tanah dan Bangunan terhadap Pendapatan Asli Daerah kemudian dapat dimasukkan dalam klasifikasi kriteria 
kontribusi yaitu sangat kurang, kurang, sedang, cukup baik, baik dan sangat baik. Berikut ini dirincikan klasifikasi tersebut:

Tabel

Klasifikasi Kriteria Kontribusi

\begin{tabular}{ll}
\hline Presentasi & Kriteria \\
\hline $0,00-10 \%$ & Sangat Kurang \\
$10,10-20 \%$ & Kurang \\
$20,10 \%-30 \%$ & Sedang \\
$30,10 \%-40 \%$ & Cukup Baik \\
$40,10 \%-50 \%$ & Baik \\
Diatas $100 \%$ & Sangat Baik \\
\hline
\end{tabular}

Sumber : Yulia Anggara Sari (2010)

\section{METODE PENELITIAN}

\subsection{Metode Penelitian}

Metode penelitian merupakan cara utama yang digunakan peneliti untuk mencapai tujuan dan menentukan jawaban atas masalah yang diajukan. Sugiyono (2014) berpendapat bahwa metode penelitian merupakan cara ilmiah untuk mendapatkan data dengan tujuan dan kegunaan tertentu.

Ada beberapa metode dalam penelitian kualitatif yaitu eksperimen, survei, historis, analisis informasi dokumenter dan studi kasus.

Tabel III.1 Perbedaan Metode Penelitian

\begin{tabular}{|l|l|l|l|}
\hline \multicolumn{1}{|c|}{ Strategi } & Bentuk Pertanyaan & \multicolumn{1}{|c|}{$\begin{array}{c}\text { Kontrol } \\
\text { terhadap } \\
\text { peristiwa } \\
\text { perilaku }\end{array}$} & $\begin{array}{c}\text { Fokus terhadap } \\
\text { peristiwa } \\
\text { kontemporer }\end{array}$ \\
\hline Eksperimen & $\begin{array}{l}\text { Bagaimana, } \\
\text { mengapa }\end{array}$ & Ya & Ya \\
\hline Survei & $\begin{array}{l}\text { Siapa, apa, } \\
\text { dimana, berapa } \\
\text { banyak }\end{array}$ & Tidak & Ya \\
\hline $\begin{array}{l}\text { Analisis } \\
\text { Arsip }\end{array}$ & $\begin{array}{l}\text { Siapa, apa, } \\
\text { dimana, berapa } \\
\text { banyak }\end{array}$ & Tidak & Ya/Tidak \\
\hline Historis & $\begin{array}{l}\text { Bagaimana, } \\
\text { mengapa }\end{array}$ & Tidak & Tidak \\
\hline
\end{tabular}




\begin{tabular}{|c|l|l|l|}
\hline Strategi & Bentuk Pertanyaan & $\begin{array}{c}\text { Kontrol } \\
\text { terhadap } \\
\text { peristiwa } \\
\text { perilaku }\end{array}$ & $\begin{array}{c}\text { Fokus terhadap } \\
\text { peristiwa } \\
\text { kontemporer }\end{array}$ \\
\hline Studi Kasus & $\begin{array}{l}\text { Bagaimana, } \\
\text { mengapa }\end{array}$ & Tidak & Ya \\
\hline
\end{tabular}

Sumber: K Yin, 2012

Mempertimbangkan faktor-faktor di atas, penulis memilih pendekatan kualitatif dengan metode studi kasus. Dalam penelitian dengan pendekatan kualitatif ini menghasilkan data deskriptif; ucapan atau tulisan dan perilaku yang diamati dari orangorang (subyek) itu sendiri.

\subsection{Spesifikasi Penelitian}

Spesifikasi penelitian ini bersifat deskriptif, karena penelitian ini merupakan suatu upaya untuk mendiskripsikan efektivitas dan kontribusi BPHTB (Bea Perolehan Hak Atas Tanah dan Bangunan) dalam rangka peningkatan pendapatan asli daerah di Kabupaten Gunung Kidul - Yogyakarta. Hal tersebut dilakukan dengan cara mengungkapkan dan memaparkan penerapan kebijakan dan metode harga transfer antara divisi terkait. Selanjutnya, hasil evaluasi tersebut dibahas dan dianalisa sehingga dapat diambil kesimpulan.

\subsection{Data dan Tehnik Pengumpulan Data}

Data untuk studi kasus bisa berasal dari enam sumber yaitu: dokumen, rekaman arsip, wawancara, pengamatan langsung, observasi partisipan dan perangkat-perangkat fisik. Pada penelitian studi kasus, data yang disebutkan dalam proposal penelitian dapat berkembang seiring berjalannya penelitian.

Data yang digunakan dalam penelitian ini adalah data sekunder, berupa data Target dan Realisasi Penerimaan BPHTB (Bea Perolehan Hak Atas Tanah dan Bangunan) serta Realisasi Penerimaan PAD (Pendapatan Asli Daerah) dari Badan Keuangan dan Aset Daerah Kabupaten Gunung Kidul.

\subsection{Analisis Data}

Analisis data kualitatif adalah upaya yang dilakukan dengan jalan bekerja dengan data, mengorganisasikan data, memilah-milahnya menjadi satuan yang dapat dikelola, mensintesiskannya, mancari dan menemukan pola, menemukan apa yang penting dan apa yang dipelajari, dan memutuskan apa yang dapat diceritakan kepada orang lain. Analisis data dilakukan sepanjang penelitian dan dilakukan secara terus menerus dari awal sampai akhir penelitian. 
Proses penelitian ini berbentuk siklus meliputi pengumpulan data, display data, reduksi data, dan penarikan kesimpulan.

\section{PEMBAHASAN}

\subsection{Badan Keuangan dan Aset Daerah (BKAD) Kabupaten Gunung Kidul}

Badan Keuangan dan Aset Daerah (BKAD) Kabupaten Gunungkidul terbentuk berdasarkan Peraturan daerah Kabupaten Gunungkidul Nomor 7 Tahun 2016 tentang Kedudukan, Susunan Organisasi, Tugas, Fungsi dan Tata Kerja Badan Keuangan dan Aset Daerah Kabupaten Gunungkidul pada Pasal 2 ayat 1 disebutkan Badan Keuangan dan Aset Daerah itu sendiri merupakan unsur penunjang Pemerintahan daerah di bidang keuangan daerah.

Sesuai rencana strategis perangkat daerah BKAD Kabupaten Gunungkidul dalam penyelenggaraan pembangunan daerah berfungsi untuk memberikan gambaran tentang program dan kegiatan prioritas terutama mengenai pengelolaan pendapatan dan keuangan serta aset daerah yang menjadi salah satu faktor pendukung keberhasilan pembangunan daerah.

Badan Keuangan dan Aset Daerah Kabupaten Gunungkidul merupakan sebuah perangkat daerah yang juga mempunyai fungsi sebagai PPKD atau Pejabat Pengelola Keuangan Daerah serta bagian yang tidak terpisahkan dari keseluruhan proses pelaksanaan pembangunan di wilayah pemerintah Kabupaten Gunungkidul utamanya yang berkenaan dengan pengelolaan keuangan daerah, diarahkan untuk mewujudkan sebuah tata pengelolaan keuangan yang akuntabel serta mendukung sebuah cita-cita luhur bangsa Indonesia untuk menuju masyarakat yang adil, makmur, sejahtera, mandiri dan bermartabat serta dalam rangka untuk mendukung Visi dan Misi Kabupaten Gunungkidul.

Sesuai dengan Instruksi Presiden Nomor 7 Tahun 1999 tentang Akuntabilitas Kinerja Instansi Pemerintah, BKAD memiliki tujuan kinerja untuk menentukan arah kebijakan BKAD dalam optimalisasi pelaksanaan program dan kegiatan serta menentukan arah kegiatan untuk meletakkan dasar sistem pengelolaan keuangan daerah yang memperhatikan kerangka regulasi dan sebagai dasar perumusan kebijakan strategis untuk dijabarkan dalam program kerja.

4.2 Analisis Efektivitas Penerimaan Bea Perolehan Hak atas Tanah dan Bangunan Kabupaten Gunung Kidul

Berdasarkan hasil penelitian, tingkat efektivitas perbandingan antara realisasi 
penerimaan BPHTB dengan target penerimaan BPHTB yang telah ditetapkan dapat dihitung sebagai berikut:

a. Efektivitas Penerimaan BPHTB tahun 2013

Efektivitas BPHTB $2013=\underline{1.509 .252 .967,00} \times 100 \%=125,77 \%$

$$
1.200 .000 .000,00
$$

b. Efektivitas Penerimaan BPHTB tahun 2014

Efektivitas BPHTB $2014=\underline{2.800 .722 .784,50} \times 100 \%=121,95 \%$

$$
\text { 2.296.554.350,00 }
$$

c. Efektivitas Penerimaan BPHTB tahun 2015

Efektivitas BPHTB $2015=\underline{5.751 .566 .075,00} \times 100 \%=237,88 \%$

$$
\text { 2.100.000.000,00 }
$$

d. Efektivitas Penerimaan BPHTB tahun 2016

Efektivitas BPHTB 2016 $=\underline{4.181 .044 .350,00} \times 100 \%=127,27 \%$

$$
\text { 3.285.050.000,00 }
$$

e. Efektivitas Penerimaan BPHTB tahun 2017

Efektivtas BPHTB $2017=\underline{5.266 .034 .276,00} \times 100 \%=115,73 \%$

$$
4.550 .000 .000,00
$$

Dari perhitungan di atas, dirangkum dalam tabel efektivitas penerimaan Bea Perolehan Hak atas Tanah dan Bangunan sebagai berikut:

\section{Tabel 2.1}

Efektivitas Penerimaan Bea Perolehan Hak atas Tanah dan Bangunan

\begin{tabular}{lccccc}
\hline No & Tahun & Target (Rp) & Realisasi (Rp) & Persentase (\%) & Kriteria \\
\hline 1. & 2013 & $1.200 .000 .000,00$ & $1.509 .252 .967,00$ & $125,77 \%$ & Sangat Efektif \\
2. & 2014 & $2.296 .554 .350,00$ & $2.800 .722 .784,50$ & $121,95 \%$ & Sangat Efektif \\
3. & 2015 & $2.100 .000 .000,00$ & $5.751 .566 .075,00$ & $237,88 \%$ & Sangat Efektif \\
4. & 2016 & $3.285 .050 .000,00$ & $4.181 .044 .350,00$ & $127,27 \%$ & Sangat Efektif \\
5. & 2017 & $4.550 .000 .000,00$ & $5.266 .034 .276,00$ & $115,73 \%$ & Sangat Efektif \\
\hline
\end{tabular}

Selama tahun 2013-2017, penerimaan Bea Perolehan Hak atas Tanah dan Bangunan selalu melebihi target yang ditetapkan. Pada tahun 2013 persentase penerimaan mencapai 125,77\%; tahun 2014 sebesar 121,95\%; tahun 2015 sebesar 237,88\%; tahun 2016 sebesar 127,27\% dan tahun 2017 sebesar 115,27\%.

Persentase penerimaan Bea Perolehan Hak atas Tanah dan Bangunan tahun 2013 
ke tahun 2014 mengalami penurunan, penerimaan tahun 2014 ke tahun 2015 mengalami kenaikan yang sangat pesat. Namun penerimaan Bea Perolehan Hak atas Tanah dan Bangunan pada tahun 2015 ke tahun 2016 kembali mengalami penurunan, begitu juga dengan penerimaan dari tahun 2016 ke tahun 2017 juga mengalami penurunan.

Meskipun secara perhitungan penerimaan Bea Perolehan Hak atas Tanah dan Bangunan selalu melebihi target dan dinyatakan dalam kriteria sangat efektif, akan tetapi Pemerintah Daerah Gunung Kidul hendaknya lebih giat lagi mengupayakan peningkatan penerimaan Bea Perolehan Hak atas Tanah dan Bangunan, sehingga persentase pencapaian dapat meningkat dan mendorong perkembangan ekonomi daerah.

\subsection{Analisis Kontribusi Penerimaan Bea Perolehan Hak atas Tanah dan Bangunan Kabupaten Gunung Kidul}

Berdasarkan hasil penelitian, tingkat kontribusi penerimaan Bea Perolehan Hak atas Tanah dan Bangunan Kabupaten Gunung Kidul dibandingkan dengan Pendapatan Asli Daerah (PAD) dapat dihitung sebagai berikut:

a. Kontribusi Penerimaan BPHTB tahun 2013

Kontribusi BPHTB $2013=1 . \underline{509.252 .967,00}$ X 100\% $=1,80 \%$ 83.427.447.822,42

b. Kontribusi Penerimaan BPHTB tahun 2014

Kontribusi BPHTB $2014=\underline{2.800 .722 .784,50}$ X 100\% $=1,75 \%$

159.304.338.220,22

c. Kontribusi Penerimaan BPHTB 2015

Kontribusi BPHTB $2015=\underline{5.751 .566 .075,00} \times 100 \%=2.93 \%$

196.099.244.204,02

d. Kontribusi Penerimaan BPHTB 2016

Kontribusi BPHTB $2016=\underline{4.181 .044 .350,00} \times 100 \%=2,02 \%$

206.278.295.665,78

e. Kontribusi Penerimaan BPHTB 2017

Kontribusi BPHTB $20117=\underline{5.266 .034 .276,00} \times 100 \%=1,94 \%$

271.370.043.388,71 
Tabel 1.8

Kontribusi Bea Peroelehan Hak atas Tanah dan Bangunan terhadap Pendapatan

Asli Daerah

\begin{tabular}{cccccc}
\hline No & Tahun & $\begin{array}{c}\text { Realisasi BPHTB } \\
(\mathbf{R p})\end{array}$ & Realisasi PAD $(\mathbf{R p )}$ & $\begin{array}{c}\text { Persentase } \\
(\boldsymbol{\%})\end{array}$ & Kriteria \\
\hline 1. & 2013 & $1.509 .252 .967,00$ & $83.427 .447 .822,42$ & $1,80 \%$ & Sangat Kurang \\
2. & 2014 & $2.800 .722 .784,50$ & $159.304 .338 .220,22$ & $1,75 \%$ & Sangat Kurang \\
3. & 2015 & $5.751 .566 .075,00$ & $196.099 .244 .204,02$ & $2.93 \%$ & Sangat Kurang \\
4. & 2016 & $4.181 .044 .350,00$ & $206.278 .295 .665,78$ & $2,02 \%$ & Sangat Kurang \\
5. & 2017 & $5.266 .034 .276,00$ & $273.370 .043 .388,71$ & $1,94 \%$ & Sangat Kurang \\
\hline
\end{tabular}

Selama tahun 2013-2017, kontribusi penerimaan Bea Perolehan Hak atas Tanah dan Bangunan (BPHTB) terhadap Pendapatan Asli Daerah (PAD) selalu dibawah angka 10\% dan dinyatakan dalam kriteria sangat kurang. Pada tahun 2013, kontribusi penerimaan Bea Perolehan Hak atas Tanah dan Bangunan (BPHTB) terhadap Pendapatan Asli Daerah (PAD) sebesar 1,80\%; tahun 2014 sebesar 1,75\%; tahun 2015 sebesar 2,93\%; tahun 2016 sebesar 2,02\% dan tahun 2017 sebesar 1,94\%.

Persentase kontribusi penerimaan Bea Perolehan Hak atas Tanah dan Bangunan tahun 2013 ke tahun 2014 mengalami penurunan, penerimaan tahun 2014 ke tahun 2015 mengalami kenaikan. Namun kontribusi penerimaan Bea Perolehan Hak atas Tanah dan Bangunan terhadap Pendapatan Asli Daerah pada tahun 2015 ke tahun 2016 kembali mengalami penurunan, begitu juga dengan penerimaan dari tahun 2016 ke tahun 2017 juga mengalami penurunan.

Pemerintah Daerah Gunung Kidul perlu melakukan evaluasi kontribusi penerimaan Bea Perolehan Hak atas Tanah dan Bangunan (BPHTB) terhadap Pendapatan Asli Daerah (PAD) yang dalam waktu 5 tahun selalu dinyatakan masuk kriteria sangat kurang. Evaluasi dapat dibandingkan dengan penerimaan pajak daerah lainnya yang mempengaruhi pendapatan asli daerah.

\section{KESIMPULAN}

\subsection{Kesimpulan}

Berdasarkan pembahasan mengenai efektivitas dan kontribusi penerimaan atas BPHTB di atas, penulis dapat menarik kesimpulan:

1. Tingkat efektivitas penerimaan BPHTB terhadap Pendapatan Asli Daerah di 
Kabupaten Gunungkidul sejauh ini sudah baik. Dimana tingkat efektivitas tersebut dapat dilihat dari hasil perhitungan selama tahun 2013 sampai 2015 yang dapat dikategorikan sangat efektif.

2. Sedangkan untuk Kontribusinya terhadap PAD, berdasarkan hasil perhitungan kontribusi BPHTB pada tahun 2013 sampai 2017 dikategorikan sangat kurang. Dari keseluruhan Kontribusi terhadap Pendapatan Asli Daerah tahun 2013 sampai 2015 termasuk kriteri sangat kurang.

\subsection{Saran}

Adapun saran yang ingin penulis sampaikan kepada Badan Keuangan dan Aset Daerah Kabupaten Gunungkidul sebagai berikut :

1. Badan Keuangan dan Aset Daerah hendaknya memberikan sosialisasi akan pentingnya pajak daerah terlebih pada pajak BPHTB agar dapat meningkatkan pendapatan asli daerah serta mempermudah layanan pengajuan BPHTB dengan cara penyederhanaan formulir pendaftaran BPHTB, pendataan, pemungutan, pelaporan dan pembayarannya. .

2. Badan Keuangan dan Aset Daerah diharapkan untuk bisa mempertahankan efektivitas penerimaan BPHTB yang sudah dicapai dan disarankan untuk bisa meningkatkan kontribusi BPHTB terhadap pendapatan asli daerah dengan cara menentukan target yang akan direalisasikan yaitu kontribusi penerimaan BPHTB serta dapat menetapkan harga jual beli tanah atau bangunan berdasarkan harga NJOP bukan berdasarkan harga NPOP.

\section{REFERENSI}

Abdul Halim. 2010. Akuntansi Daerah Sektor Publik. Jakarta : Salemba 4.

Bungkaes, H. R., Posumah, J. H., \& Kiyai, B. (2013). Hubungan Efektivitas Pengelolaan Program Raskin dengan Peningkatan Kesejahteraan Masyarakat di Desa Mamahan Kecapatan Gemeh Kabupaten Kepulauan Talaud. Journal “Acta Diurna”.

Mardiasmo. (2016). Perpajakan. Edisi Terbaru 2016. Yogyakarta: Andi.

Papang Permadi P dan Ariyadi Rimawan. 2014. Analisis Kontribusi Pajak Daerah terhadap Pendapatan Asli Daerah Kabupaten Gunung Kidul. Jurnal Kajian Bisnis, Vol. 22, No. 1. 
Sari, Yulia Anggara. 2010. Analisis Efektifitas dan Kontribusi Penerimaan Pajak Bumi dan Bangunan Terhadap Pendapatan Daerah di Kota Bandung. Jurnal Wacana Kinerja, Vol 13 No.2, November 2010: 173-185.

Siti Resmi. 2013. Perpajakan Teori dan Kasus. Edisi (. Buku 1). Jakarta: Salemba Empat.

Soemitro, Rochmat. 2012. Perpajakan. Yogyakarta: Andi.

Soekanto, Soerjono. 2015. Sosiologi Suatu Pengantar. Jakarta: Rajawali Pers.

Sugiyono. 2014. Metode Penelitian Kuantitatif, Kualitatif, dan R\&D. Bandung: Alfabeta.

Undang-undang Nomor 28 Tahun 2009 tentang Pajak Daerah dan Retribusi Daerah dan Peraturan Pemerintah Nomor 65 tahun 2001 tentang Pajak Daerah.

UU No. 34/2000 tentang Perubahan atas Undang-undang Republik Indonesia Nomor 18 Tahun 1997 tentang Pajak Daerah dan Retribusi Daerah.

Yin, R. K. (2012). Studi Kasus, Desain \& Metodologi. Jakarta: Raja Grafindo Persada 